\title{
THE POLITICAL COMMUNICATION STRATEGY OF PARTAI GOLONGAN KARYA IN REGIONAL HEAD ELECTION YEAR 2018
} (Case Study Study at DPD Partai Golongan Karya In Bengkulu City)

\section{STRATEGI KOMUNIKASI POLITIK PARTAI GOLONGAN KARYA PADA PEMILIHAN KEPALA DAERAH TAHUN 2018 (Studi Pada DPD Partai Golongan Karya Di Kota Bengkulu)}

\author{
Haris Sasilo, Sapta Sari, Indria \\ Program Studi IImu Komunikasi Fakultas IImu-IImu Sosial \\ Universitas Dehasen Bengkulu
}

Email: sapta.sari26@gmail.com, ria.kisum@gmail.com

\begin{abstract}
How to Cite :
Sasilo .H, Sari.S., Indria . I. (2020). THE POLITICAL COMMUNICATION STRATEGY OF PARTAI GOLONGAN KARYA IN REGIONAL HEAD ELECTION YEAR 2018 (Case Study Study at DPD Partai Golongan Karya In Bengkulu City). SENGKUNI Journal- Social Sciences and Humanities. DOI: https://doi.org/10.37638/sengkuni.1.1.87-97
\end{abstract}

\section{ARTICLE HISTORY}

Received [9 Maret 2020]

Revised [12 April 2020]

Accepted [27 April 2020]

\section{KEYWORDS}

Political Communication

Strategy, Regional

Representative Board Of

Golkar Party, Local Election

This is an open access article under the $\underline{C C-B Y-S A}$ license

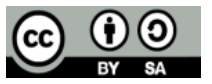

\section{ABSTRAK}

Penelitian ini bertujuan untuk mengetahui strategi komunikasi politik Partai Golongan Karya (Golkar) pada pemilihan kepala Daerah tahun 2018. Teknik pengambilan data yang peneliti gunakan adalah wawancara, dokumentasi, dan observasi. Teknik pengambilan data dengan cara purposive sampling dengan mengambil informan sebanyak 3 orang. Penelitian ini menggunakan metode deskriptif kualitatif dengan menggunakan teori positioning dari Adam Nursal (Andianus Pito : 2013), terdiri dari : 1). policy merupakan tawaran program kerja yang di sampaikan oleh kandidat kepada masyarakat, 2). person adalah seorang kandidat yang mempunyai nilai kualitas dan track record nya tinggi, 3). party ini merupakan produk politik yang sudah diperbuat oleh partai Golkar, 4). presentation adalah adanya pemaparan program kerja yang disampaikan oleh Partai Golkar kepada masyarakat secara langsung. Adapun hasil dari penelitian dan pembahasan bahwa teori positioning yang dilakukan oleh DPD Partai Golongan Karya (Golkar) mampu mengambil simpati dan dapat mempengaruhi dari pesan yang disampaikan ke masyarakat.

\section{ABSTRACT}

This study aims to determine the political communication strategy of the golongan karya (golkar) party in regional head elections. Data retrieval techniques that researchers use are interviews, documentation, and observation. Data collection techniques by purposive sampling by taking informants as many as 3 people. This study uses a qualitative descriptive method using the positioning theory from adam nursal (andianus pito : 2013) consisting of: 1) policy is an offer of work programs delivered by candidates to the pubic 2)person is a candidata who has a high quality and track record 3). This party is apolitical product that has been done by the golkar party 4). 
Presentation is the presentation of work programs submitted by the golkar party to the pubic directly. The results of the research and discussion that the positioning theory carried out by the DPD golongan karya (golkar) party is able to take sympathy and can influence the message conveyed to the public.

\section{PENDAHULUAN}

Partai Golongan Karya (Golkar) adalah salah satu partai politik yang ada di Indonesia,partai ini memiliki gambar atau logo berbentuk sebuah pohon beringin. Partai golkar merupakan yang berasaskan pancasila dan bersipat mandiri, terbuka, demokratis, moderat, solid, mengakar, responsif, majemuk, egaliter, serta berorientasi pada karya dan kekaryaan. Pemilu melalui satu nama dan tanda gambar yaitu Golongan Karya (Golkar). Logo dan nama ini, sejak Pemilu 1971, tetap dipertahankan sampai sekarang. Pada Pemilu 1971 ini, Sekber Golkar ikut serta menjadi salah satu konsestan. Pihak Parpol memandang remeh keikutsertaan Golkar sebagai kontestan Pemilu. Mereka meragukan kemampuan komunikasi politik Golkar kepada grassroot level.

Didalam menghadapi pemilihan pilkada partai Golkar harus kerja keras agar bisa mempertahankan dan sekaligus bisa meningkatkan kepercayaan masyarakat kepada partai Golkar dan harus mempunyai strategi komunikasi politik dengan baik. Dalam arti kata bahwa pendekatan yang dilakukan kepada khalayak, berhasil atau tidaknya sangat ditentukan oleh strategi komunikasi yang dilakukan pada saat kompanye politik. Singkatnya dalam kancah perpolitikan peran politik merupakan tonggak keberhasilan atau kegagalan sebuah partai. Pada pilkada Kota Bengkulu tahun 2018, partai ini mengusung pasangan Ir. Patriana Sosialinda dengan pasangan nya Mirza SH, M.kn, maka partai Golkar harus bekerja keras dan saling kerja sama yang baik, dimulai dari kader yang ada di kelurahan, kecamatan, dan kader tingkat DPD kota dan Propinsi bahkan DPP Pusat agar pasangan ini dipilih oleh masyarakat dan menjadikan pemimpin Kota Bengkulu untuk 5 tahun kedepan nya. Didalalam managemen partai politik yang baik dapat mengubah partai kecil menjadi sebuah partai besar yang populer, sebaliknya dalam managemen partai politik yang buruk dapat menjatuhkan nama baik dan mengubah dari partai besar yang bersangkutan dimata masyarakat.

Komunikasi politik merupakan komunikasi yang melibatkan pesan-pesan politik dan aktor-aktor politik yang selalu berkaitan dengan kekuasaan, pemerintahan dan kebijakan pemerintah. Komunikasi politik menurut para pakar bahwa "komunikasi politik itu adalah suatu proses dan kegiatan-kegiatan membentuk sikap dan perilaku politik yang terintegrasi ke dalam suatu sistem politik dengan menggunakan simbol-simbol yang berarti. Komunikasi politik bukan membahas suatu proses yang bersifat temporer atau situasional tertentu, akan tetapi pembahasan komunikasi politik akan menampakkan karakter sebagai identitas keilmuanm baik sebagai ilmu murni yang bersifat ideal dan berada dalam lingkup "Das Sollen", maupun berupa ilmu terapan yang berada dalam dunia empiris dalam lingkup wilayah "Das Sein".sebagai sebuah ilmu terapan, komunikasi politik bukanlah hal yang baru. Komunikasi politik juga bisa dipahami sebagai komunikasi antara "yang memerintah" dan "yang diperintah".

Mengkomunikasikan politik tanpa aksi politik yang kongkret sebenarnya telah dilakukan oleh siapa saja: mahasiswa, dosen, tukang ojek, penjaga warung, dan masyarakat biasa. Tak heran jika ada yang menjuluki komunikasi politik sebagai neologisme, yakni ilmu yang sebenarnya tak lebih dari istilah belaka. Berdasarkan hal tersebut, maka strategi komunikasi sangatlah diperlukan untuk meningkatkan 
kepercayaan pada partai Golkar kepada masyarakat sehingga bisa menjadi partai yang lebih unggul dibandingkan dengan partai lainnya. Adapun tujuan penelitian ini adalah untuk mengetahui Strategi Komunikasi Politik Partai Golongan Karya (Golkar) pada pemilihan kepala daerah (Pilkada) Tahun 2018.

\section{LANDASAN TEORI}

\section{Pengertian Strategi}

Kata strategi berasal dari kata strategos dalam bahasa Yunani merupakan gabungan dari stratosatau tentara dan ego atau pemimpin. Suatu strategi mempunyai dasar atau skema untuk mencapai sasaran yang dituju. Jadi pada dasarnya strategi merupakan alat untuk mencapai tujuan. Strategi adalah sebagai suatu proses penentuan rencana para pemimpin puncak yang berfokus pada tujuan jangka panjang organisasi, disertai penyusunan suatu cara atau upaya bagaimana agar tujuan tesebut dapat tercapai. (marrus, 2002:31).

\section{Komunikasi Politik}

Menurut Dahlan (1999), komunikasi politik ialah suatu bidang atau disiplin yang menelaah perilaku dan kegiatan komunikasi yang bersifat politik, mempunyai akibat politik, atau berpengaruh terhadap perilaku politik. Dan dapat juga dirumuskan bahwa suatu proses pengoperan lambang-lambang atau simbol-simbol komunikasi yang berisi pesan-pesan politik dari seseorang atau kelompok kepada orang lain dengan tujuan untuk membuka wawasan atau cara berpikir, serta mempengaruhi sikap dan tingkah laku khalayak yang menjadi target politik.

Dengan demikian, melalui kegiatan komunikasi politik terjadi pengaitan masyarakat sosial dengan lingkup negara sehingga komunikasi politik merupakan sarana untuk pendidikan politik/kesadaran warga dalam hubungan kenegaraan (Anwar Arifin, 2006: 8-9). Menurut Anwar Arifin (2011:125) Beberapa bentuk atau jenis seni dan teknik aplikasi komunikasi politik yang sudah lama dikenal dan dilakukan oleh para politikus atau aktivis politik, antara lain retorika politik, agitasi politik, pro-paganda politik, lobi politik, dan tindakan politik yang dapat dilakukan dalam kegiatan politik yang terorganisir seperti : public relations politik, pemasaran politik, dan kampanye politik. Semua bentuk komunikasi politik itu berkaitan dengan pembentukan citra dan opini publik yang positif.

Hal itu dapat berkaitan dengan upaya memenangkan pemilu agar dapat meraih kekuasaan dan kedudukan politik di lembaga legislatif atau eksekutif sehingga dapat membuat kebijakan politik yang sesuai dengan visi misi dan program politik para komunikator politik terutama para politikus dan partai politiknya. Menurut Anwar Arifin (2011:235) strategi dalam komunikasi politik adalah keseluruhan keputusan kondisional tentang tindakan yang akan dijalankan saat ini, guna mencapai tujuan politik pada masa depan. Justru itu keberadaan pemimpin politik sangat dibutuhkan disetiap aktivitas kegiatan komunikasi politik.

\section{Partai Politik}

Bagi suatu negara yang menganut sistem membangun pross demokrasi, partai politik menjadi sarana demokrasi yang bisa berperan sebagai penghubung antara rakyat dan pemerintah. Pembentukan partai politik berdasarkan atas prinsip-prinsip demokrasi, yakni pemerintahan yang dipimpin oleh mayoritas melalui pemilihan umum. Untuk menciptakan pemerintahan yang mayoritas, diperlukan partai-partai yang dapat digunakan sebagai kendaraan politik untuk ikut dalam pemilihan umum. 
Carr (1965),berpendapat bahwa partai politik adalah suatu organisasi yang berusaha untuk mencapai dan memelihara pengawasan pemerintahan. Pengertian yang hampir sama juga dikemukakan oleh Budiarjo (2002: 161) bahwa partai politik adalah suatu kelompok yang terkelola yang anggota-anggotanya mempunyai orientasi, nilai-nilai, dan cit-cita yang sama. Tujuan kelompok ini ialah untuk memperoleh kekuasaan politik atau merebut kedudukan politik dengan cara konstitusional untuk melaksanakan kebijaksanaan-kebijaksanaan umum. Sementara itu, pengertian partai politik menurut undang-undang No.31 Tahun 2002 Republik Indonesia dinyatakan bahwa partai politik adalah organisasi politik yang dibentuk oleh sekelompok warga negara Republik Indonesia secara sukarela atas dasar persamaan kehendak dan cita-cita untuk memperjuangkan kepentingan anggota, masyarakat, bangsa, dan negara melalui pemilihan umum.

\section{Pemilihan Kepala Daerah (Pilkada)}

Pelaksanaan pilkada langsung merupakan sebuah peningkatan demokrasi ditingkat lokal,dengan adanya demokrasi dalam sebuah negara, berarti dalam negara tersebut menjalankan demokrasi yang menjunjung tinggi aspirasi, kepentingan dan suara rakyat. Menurut Winarno (2002:11) mengatakan bahwa "sistem pemilihan secara langsung merupakan alternatif yang paling realistis guna mendekatkan aspirasi demokrasi rakyat dengan kekuasaan pemerintah dan pada saat yang sama memberikan basis legitimasi politik kapada pejabat eksekutif yang terpilih".

Pemilihan kepala daerah dan wakil kepala daerah secara langsung diatur dalam Undang-Undang No.32 Tahun 2004 tentang pemerintahan daerah pasal 56, pasal 119 dan peraturan pemerintah No.6 Tahun 2005 tentang tata cara pemilihan, pengesahan, pengangkatan, dan pemberhentian kepala daerah dan wakil kepala daerah. Pilkada langsung sebagai pembelajaran politik yang mencakup tiga aspek yaitu:

a) Meningkatakan kesadaran politik masyarakat lokal

b) mengorganisir masyarakat kedalam suatu aktivitas politik yang memberikan peluang lebih besar pada setiap orang untuk berpartisipasi,

c) memperluas akses masyarakat lokal untuk mempengaruhi proses pengambilan keputusan yang menyangkut kepentingan mereka.

Selain itu, hal yang terpenting dari pilkada adalah sebuah sarana demokratisasi ditingkat lokal yang dapat menegakkan kedaulatan rakyat dalam penyelenggaraan pemerintahan daerah dan calon yang terpilih akan kuat legitimasinya karena dipilih langsung oleh rakyat sehingga tercipta stabilitas politik dalam pemerintahan daerah , Menurut Firiyah (2005).

\section{Positioning}

Positioning menurut Adam Nursal dalam Toni Andianus Pito (2013:206).agar kredibel dan efektif Positioning ini harus dijabarkan dalam bentuk produk politik meliputi:

1) Policy adalah tawaran program kerja jika terpilih kelak. Policy merupakan solusi yang ditawarkan kontestan untuk memecahkan masalah-masalah masyarakat berdasarkan isu-isu yang dianggap penting oleh para pemilih. Policy yang efektif harus memenuhi tiga syarat, yaitu : menarik perhatian, mudah terserap pemilih, atribut.

2) Person adalah kandidat legislatif atau eksekutif yang akan dipilih melalui pemilu. Kualitas person dapat dilihat melalui tigadimensi, yaitu : kualitas instrumental, dimensi simbolis dan fenotipe optik, dimensi kualitas. 
3) Party dapat juga sebagai substansi produk politik. Partai mempunyai identitas semua, aset reputasi, dan identitas estetik. Ketiga hal tersebut akan dipertimbangkan oleh para pemilih dalam menetapkan pilihannya.

4) Presentasion adalah bagaimana ketiga substansi produk politik (policy, person, party) disajikan. Presentasi sangat penting karna dapat mempengaruhi makna politis yang terbentuk dalam pikiran para pemilih.

\section{METODE PENELITIAN}

Penelitian ini mengggunakan penelitian kualitatif. Untuk tipe penelitian ini peneliti mengkonstruksikan wawancara yang mendalam terhadap objek informan bagaimana strategi yang dijalankan sehingga mengetahui informasi serta bentuk strategi komunikasi apa yang digunakan oleh DPD partai Golkar dalam pemilihan Kepala Daerah. Dalam penelitian ini peneliti menetapkan informan penelitian berdasarkan teknik purposive sampling yaitu teknik penentuan informan dengan cara pengambilan sumber data (sugiyono, 2012:18).

Peneliti menentukan sendiri dari informan yang diambil dari orang-orang yang dianggap memahami persoalan terkait permasalahan penelitian dalam hal ini DPD partai Golkar Kota Bengkulu yakni :

1. Wakil Ketua Bagian Organisasi Dan Ormas Pada DPD Partai Golkar Kota Bengkulu.

2. Wakil Ketua Bagian Pemenangan Pemilu Dapil 1 Pada DPD Partai Golkar Kota Bengkulu.

3. Wakil Ketua Bagian Pemenangan Pemilu Dapil 2 Pada DPD Partai Golkar Kota Bengkulu.

Metode analisis data yang dilakukan meliputi pengumpulan data, pengolahan atau reduksi data, penyajian data, dan penarikan kesimpulan.

\section{HASIL DAN PEMBAHASAN}

\section{HASIL PENELITIAN \\ Strategi Komunikasi Politik Partai Golongan Karya (Golkar) Pada Pemilihan Kepala Daerah Dilihat Dari Teori Adam Nursal (2013:206).}

Strategi positioning politik merupakan hal yang penting yang harus dilakukan partai politik, khususnya dalam kompetisi politik di pemilihan umum. Strategi positioning politik akan membantu pemilih dalam menentukan siapa yang akan dipilihnya, Ries \& Trout, mendefinisikan Positioning dalam marketing politik sebagai semua aktivitas untuk menanamkan kesan di benak konsumen agar mereka bisa membedakan produk dan jasa yang dihasilkan oleh organisasi yang bersangkutan (Firmanzah, 2011).

Dalam positioning, atribut barang dan jasa yang dihasilkan akan direkam dalam bentuk image yang terdapat dalam sistem kognitif konsumen. Semakin tinggi image yang direkam dalam benak konsumen, maka semakin mudah pula mereka mengingat image tersebut, atau dalam istilah politik kita kenal dengan citra politik. Dalam konteks politik, image yang dimaksud misalnya kredibilitas seorang politisi, track record, pendidikan, dan reputasi semuanya dapat digunakan sebagai media positioning politik.

Sesuatu yang berbeda (diferensiasi) perlu diditegaskan dalam positioning politik, karena akan memudahkan masyarakat dalam membedakan produk satu partai dari partai lainnya, sehingga tertanam dalam benak masyarakat itu sendiri. Akan tetapi, terdapat permasalahan mendasar dalam positioning politik adalah penciptaan image 
yang konsisten yang mengerucut pada suatu tema tertentu dimana image politiknya terdiri dari program kerja partai, isu politik, dan image pemimpin partai.

Dalam strategi positioning politik pun sama halnya dengan bauran marketing politik yakni harus memiliki segmentasi pemilih dalam positioning-nya. Segmentasi atau pemetaan ini penting dilakukan untuk mengingat institusi politik yang diharapkan dapat selalu hadir dalam berbagai karakteristik pemilih. institusi politik perlu melakukan segementasi politik, disebabkan ada beberapa haldidalam proses dinamika pemilihan umum dibutuhkan sebuah langkah strategi untuk mencapai tujuan politik agar komunikasinya lebih efektif dan bisa diterima oleh masyarakat.

\section{Policy}

Policy ini merupakan sebuah tawaran program kerja. Kebijakan yang merupakan solusi yang ditawarkan kontestan untuk memecahkan masalah kemasyarakatan berdasarkan isu-isu yang di anggap penting oleh para pemilih. Kebijakan yang efektif harus memenuhi tiga syarat, yaitu : menarik perhatian, mudah terserap pemilih, dan dimensi kualitas. Seorang kandidat/calon sebagai kepala daerah sebelum menjadi kepala daerah bahkan sudah menjadi kepala daerah, haruslah sejalan dengan keinginan sebuah partai yang mengusungnya. Hal ini juga masuk didalam visi dan misi kandidat yang diusung oleh partai Golkar yaitu Ibu Ir. Patriana Sosialinda dan pasangan nya Bapak Mirza SH, M.kn yaitu mewujudkan Kota Bengkulu yang berbudaya dan memajukan kota Bengkulu yang lebih baik lagi. Rencana kerja yang akan dilaksanakan Linda-Mirza apabila menjadi Walikota dan Wakil Walikota Bengkulu tak hanya soal pembangunan infrastruktur, pelayanan kesehatan bagi masyarakat miskin serta akses jalan pendidikan yang layak, pengolahan sampah serta akses permodalan.

Rencana kerja itu sebagai upaya untuk menjadikan Kota Bengkulu maju, makmur dan berbudaya. Dan tugasnya mengatur kehidupan disemua lini sendi kehidupan yang ada di Kota, mengatur dengan cara memberikan pelayanan publik, menyiapkan sarana prasarana infrastruktur perkotaan, jadikan Kota Bengkulu ini seperti Kota yang sesungguhnya.meningkatkan pelayanan lampu jalan, jalan yang dilewati khususnya arah pelayanan pendidikan, pelayanan kesehatan, rumah ibadah, sentra-sentra produksi harus mulus.

\section{Person}

Person adalah merupakan kandidat yang akan di pilih melalui pemilu. Kandidat harus memiliki nilai jual dimana track recordnya dalam politik sangat dipertanyakan. Kualitas person dapat dilihat melalui tiga dimensi, yaitu : Kualitas instrumental, Dimensi simbolik dan fenotipe optik, Dimensi kualitas.

Berdasarkan dari hasil observasi dan wawancara yang berlangsung kepada pihak yang terkait dapat ditarik kesimpulan bahwa seorang kandidat itu mempunyai adanya dedikasi dan loyalitas yang tinggi terhadap sebuah partai maupun kepada masyarakat umum. Didalam memilih seorang sebagai kandidat Kepala Daerah, Partai Golkar telah menjaring beberapa kandidat dan kemudian timbul lah kesepakatan di internal partai itu sendiri bahwa Ir. Patriana Sosialinda lah yang pas untuk maju dan di usung karena banyak hal harus di pertimbangkan mengapa harus memilih sosok seorang Patriana Sosialinda yang harus dipilih karena banyak perempuan muda di Kota Bengkulu pada decade tahun 80 -an aktif terjun dalam kegiatan organisasian sosial, dan politik.

Pada era itu perempuan muda cenderung melakukan kegiatan-kegiatan lain yang dinilai hanya milik perempuan semata. Tapi malah sebaliknya sosok Putri Bengkulu berdarah Rejang dilahirkan di Jakarta pada tanggal 28 November 1965 yakni Ir. Patriana Sosialinda adalah wanita yang tangguh, gigih dan mandiri. Sang ayah Drs. 
H. Syaffiudin. AR (Alm) mantan walikota Bengkulu era tahun 1975-1980. Kepedulian yang tinggi terhadap masyarakat mendorong Linda muda untuk terjun kedalam beberapa organisasi sosial kemasyarakatan dan kepemudaan seperti KNPI Provinsi Bengkulu, Gema Kosgoro menjabat sebagai ketua bidang peranan perempuan seni dan budaya, GM Kosgoro Provinsi Bengkulu sebagai bendahara, Depidar Soksi Provinsi Bengkulu sampai dengan saat ini dengan menjabat sebagai Wakil Ketua. Dalam organisasi kemasyarakatan ia juga aktif didalam kelompok-kelompok pengajian dan menjadi Dewan Penasihat BKMT Kota Bengkulu.

Partai Golkar menjadikannya wakil Bendahara tahun 2004-2009 dan jabatan Wakil Ketua DPD Partai Golkar Kota Bengkulu. Duduk dikursi legislatif DPRD Kota Bengkulu tahun 2004 sampai 2012. Memasuki periode kedua tahun 2009 ia dipercaya menjabat salah satu unsur pimpinan DPRD yaitu sebagai Wakil Ketua DPRD Kota Bengkulu. Patriana Sosialinda terpilih sebagai wakil walikota Bengkulu periode 20132018 berpasangan dengan Helmi Hasan. Melihat dari rekam jejak itulah partai Golkar mengamanahkan kepada Ir, Patriana Sosialinda dengan pasangan nya Mirza, SH M.kn. Bakal calon wakil walikota Bengkulu Mirza, SH, M.Kn, yang mendampingi bakal calon walikota Patriana Sosialinda diprediksi memiliki kans yang cukup kuat untuk bisa memenangkan Pilwakot Bengkulu. Sebab putra dari anggota DPR RI Elva Hartati dan Dadang Misha Yoftie ini sudah dikenal merakyat dimata masyarakat Kota Bengkulu.

Sebagai Ketua Umum DPC PDIP Kota Bengkulu dan juga sebagai figur muda, Mirza pun bukanlah anak kemarin sore yang belum memiliki pengalaman dan merasakan bagaimana hidup dalam sebuah polemik dan permasalahan. Ayah dari Gibran Nabil Mirza dan Keenan Malik Mirza ini terbukti pernah terlibat dan berperan aktif di berbagai organisasi. Diantaranya sebagai Sekretaris Ikatan Notaris Indonesia Provinsi Bengkulu dan Ketua Komisi Hukum dan Advokasi Ikatan Motor Indonesia (IMI) Provinsi Bengkulu. Di organisasi kemasyarakatan lainnya, Mirza juga menjabat sebagai Wakil Ketua Bidang Koperasi dan UKM Gerakan Nelayan dan Tani Indonesia Provinsi Bengkulu. Dan ini juga alasan mengapa mengandeng seorang mirza sebagai calon wakil nya.

\section{Party.}

Dapat dilihat sebagai subtansi produk politik. Partai / kandidat harus mempunyai identitas utama, aset reputasi dan identitas estetik. Ketiga hal tersebut akan dipertimbangkan oleh para pemilih dalam menetapkan pilihannya. Oleh karena itu, dalam political marketing unsur-unsur tersebut harus di kelola dengan baik. Pembuatan produk politik itu sudah banyak dilakukan oleh kader-kader partai karena semua kader yang direkrut itu sudah ditempah terlebih dahulu sebelum bergabung di kader golkar dan harus mengikuti yang dicanangkan oleh pengurus pusat. Melihat dari rekam jejak kandidat yang di usung maka kedua pasangan Ir. Patriana Sosialinda dan Mirza, SH, M.kn ini sudah melakukan prestasi yang cukup untuk mendogkrak suara untuk memenangi kontestasi pada pilkada, di tmbah lagi dengan visi dan misi mereka yang mampu akan medulang suara.

\section{Presentation.}

Presentation adalah bagaimana ketiga subtansi produk politik (policy, person, party) disajikan. Presentasi ini sangat penting karena dapat mempengaruhi makna politis yang terbentuk dalam pikiran para pemilih. Presentasion disajikan melalui medium presentasi yang secara umum dapat dikelompokkan dengan menjadi obyek fisik, orang dan even.

Produk - produk yang disajikan itu haruslah bersentuhan langsung dengan masyarakat yaitu melalui kader-kader, di mulai dari tingkat kelurahan sampai ke tingkat 
DPP yang memberikan pemahaman kepada masyarakat luas sejalan dengan visi dan misi kandidat yang di usung oleh partai Golkar yaitu “ mewujudkan kota Bengkulu maju, makmur, dan berbudaya" agar ada perubahan pada Kota Bengkulu untuk 5 (lima) Tahun kedepannya. Tujuan program tersebut tidak hanya dikatakan muluk-muluk agar bisa berharap dapat menjalankan visi dan misinya bersama pasanganya Mirza dari Partai PDIP sesuai visi dan misi, menuju Kota Bengkulu maju, makmur dan berbudaya sesuai maknanya, dikarenakan Kota tidak maju tanpa budaya, nilai akhlaknya, adat istiadatnya, sehingga dapat membentuk karakter yang baik.

\section{PEMBAHASAN}

Bagi Partai Golkar untuk meningkatkan dan mendulang suara terbanyak pada pemilihan kepala daerah kota Bengkulu tahun 2018 yakni dengan mengunakan tawaran kerja dalam hal ini apabila kandidat tersebut terpilih menjadi seorang kepala daerah yaitu mempunyai program yang nyata bagi masyarakat umum di mulai dari masyarakat kalangan bawah sampai ke kalangan atas.Dengan adanya penyampaian program-program tersebut agar tersmapakan untuk umum yakni dengan cara menyampaikan visi dan misi nya secara terbuka untuk umum.

Adapun visi dan misi kandidat yang di usung oleh partai Golkar itu adalah : Visi

Mewujudkan kota Bengkulu Maju, Makmur, Dan Berbudaya Misi

- Menjadikan kota Bengkulu yang Berbudaya agar Berahlak yang baik

- Menjamin kesehatan tanpa ada perbedaan antara miskin dan kaya

- Menjamin sekolah dimulai dari tingkat Sekolah Dasar sampai tingkat Sekolah Menengah Atas Gratis tuntas dan Berkualitas

- Meciptakan Lapangan Pekerjaan agar menjadikan ekonomi yang kuat dan bisa Berdaya Saing

- Pembangunan Infrastruktur perkotaan untuk menuju kota wisata terintegrasi yang berbasis lingkungan

- Menjadikan kota Bengkulu yang Ramah dan Layak Anak (BRLA), Bengkulu Ramah dan Layak Perempuan (BRLP), Bengkulu Kota Tanpa Kumuh (BKOTAKU) serta Bengkulu Waspada Bencana (BWB)

- Dalam menyampaikan visi dan misi tersebut adalah kandidat yang diusung oleh partai Golkar bertujuan untuk masyarakat agar bisa mengenali kandidat lebih dekat. Itulah sebaiknya kandidat yang diusung oleh partai Golkar haruslah individu-individu selalu dekat dengan rakyat yang bisa mendengar, mengetahui apa keinginan masyarakat.

- Adapun Kualitas person yang akan dipilih oleh partai itu dapat dilihat melalui tigadimensi, yaitu : kualitas instrumental, dimensi simbolis dan fenotipe optik, dimensi kualitas. Didalam menentukan seserong menjadi calon atau kandidat, dari partai golkar itu mempunyai syarat dan ketentuan seperti halnya kualitas dan kuantitas serta tret record nya yang baik di mata masyarakat agar seorang kandidat tersebut bisa terpilih oleh masyarakat.Terkaitdengan sosok figur pasangan untuk membuat pemilih lebih yakin bahwa ideologi partaidan kandidat sesuai dengan mereka. Didalam menentukan kandidat di partai Golkar melalui mekanisme yang panjang dimulai adanya penjaringan dan pengkajian yang membutuhkan proses panjang kemudian menentukan siapa yang pantas diusung oleh partai. 
Keterangan : Pendaftraran Calon Kepala Daerah oleh DPD Partai Golkar

Dengan proses yang panjang maka dari DPD Golkar Kota Bengkulu menentukan dan menetapkan Ir. Patriana Sosialinda yang pantas untuk di usung karena treck recort nya yang mampu memajukan kota Bengkulu kedepannya beberapa organisasi sosial kemasyarakatan dan kepemudaan seperti KNPI Provinsi Bengkulu, Gema Kosgoro menjabat sebagai ketua bidang peranan perempuan seni dan budaya, GM Kosgoro Provinsi Bengkulu sebagai bendahara, Depidar Soksi Provinsi Bengkulu sampai dengan saat ini dengan menjabat sebagai Wakil Ketua. Dalam organisasi kemasyarakatan ia juga aktif didalam kelompok-kelompok pengajian dan menjadi Dewan Penasihat BKMT Kota Bengkulu. Kegiatan sosial dan politik yang dijalaninya akhirnya menghantarkan ia pada kursi legislatif DPRD Kota Bengkulu tahun 2004 sampai 2012. Memasuki periode kedua tahun 2009 ia dipercaya menjabat salah satu unsur pimpinan DPRD yaitu sebagai Wakil Ketua DPRD Kota Bengkulu, menjadi Ketua DPD Partai Golkar Kota Bengkulu sampai saat ini.sebagai wakil walikota Bengkulu periode 2013-2018. Melihat dari rekam jejak itulah partai Golkar mengusung Ir. Patriana Sosialinda sebagai kandidat calon kepala daerah di kota Bengkulu.

Partai mempunyai identitas semua, aset reputasi, dan identitas estetik. Ketiga hal tersebut akan dipertimbangkan oleh para pemilih dalam menetapkan pilihannya. salah satunya mengundang para pemilih dalam suatu kegiatan, dan juga melakukan pendekatan dengan cara turun langsung kedalam masyarakat. Dan cara tersebut akan dinilai sangat berpengaruh untuk mendapatkan. Agar diketahui oleh masyarakat dan apa yang ingin dilakukan maka perlu terobosan yaitu dengan cara melihat langsung dilapangan dan blusukan-blusukan apa yang telah terjadi dan menjadikan catatan untuk dilaksanakan apabila terpilih nantinya.

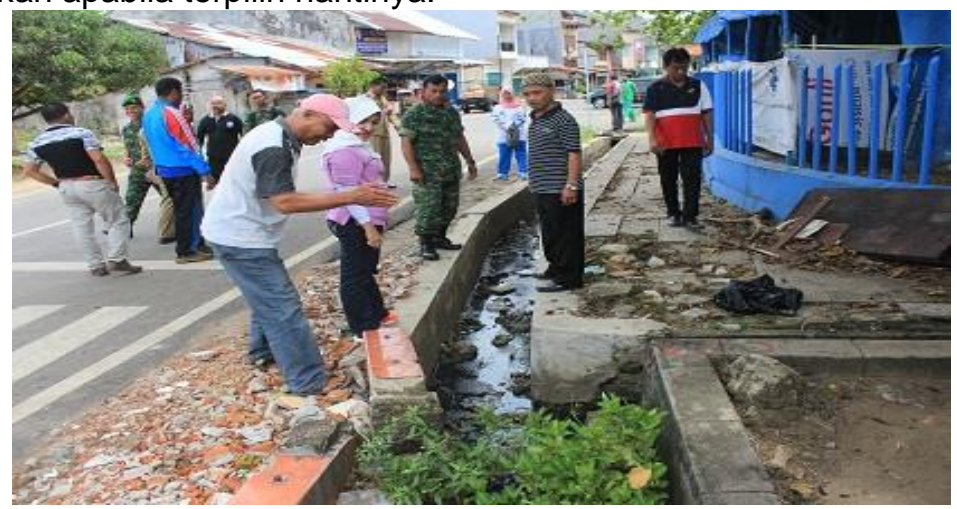

Keterangan : Blusukan Calon Kepala Daerah

Presentasi sangat penting karna dapat mempengaruhi makna politis yang terbentuk dalam pikiran para pemilih. Partai Golongan Karya memperjuangkan aspirasi 
dan berbuat untuk masyarakat adalah kewajiban utama partai politik.permasalahan pemilih menjatuhkan pilihannya,dikembalikan kepada hati nurani pemilih yang bersangkutan yang penting informasi yang diberikan adalah benar dan bukan janji-janji kosong. Melaksanakan penyampaian visi, misi dan program partaidengan temu secara langsung menemui masyarakat secara door to door ataumelakukan diskusi ataupun kegiatan kemasyarakatan. Melakukan retorika politik secara sederhanadan santun kemudian anggota legislatif vokal menyuarakan aspirasi masyarakat,serta penunjukkan juru kampanye. Melaksanakan kampanye politik dilapangan terbuka dalammensosialisasikan visi, misi dan program kerja partai dan caleg. Penggunaanmedia cetak / elektronik serta alat peraga kampanye untuk menyentuh masyarakat.

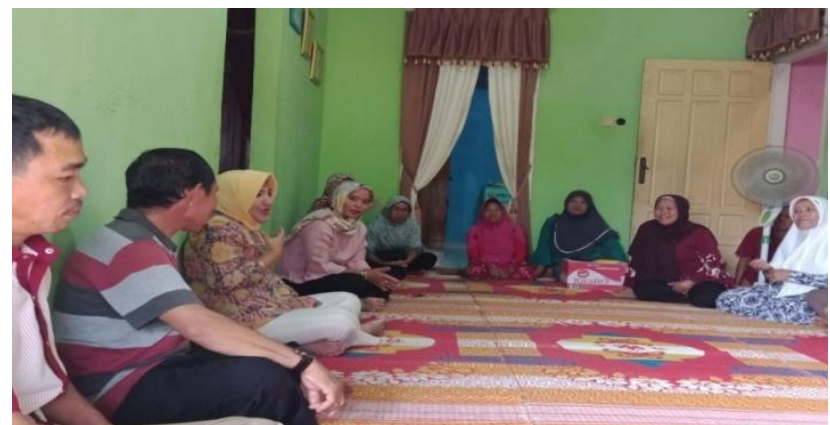

Keterangan : $\quad$ Calon Kepala Daerah Sosialisasi door to door berdiskusi kepada masyarakat

\section{KESIMPULAN DAN SARAN}

\section{Kesimpulan}

Berdasarkan dari hasil penelitian dan pembahasan yang dipaparkan dari Babsebelumnya, maka peneliti dapat menyimpulkan bahwa didalam menentukan seorang kandidat kepala daerah haruslah diperhatikan sebagai berikut :

Seorang kandidat yang di usung oleh partai Golongan Karya (Golkar) mempunyai program kerja yang nyata untuk masyarakat di mulai dari masyarakat bawah sampai ke masyarakat atas Seorang kandidat yang di usung dari partai Golkar mempunyai treck recort nya yang teruji. Seorang kandidat kepala daerah yang dari partai Golkar harus mempunyai sosial yang tinggi dan mengetahui apa yang keinginan oleh masyarakat Seorang kandidat dari partai Golkar harus bisa menyampaikan langsung kepada masyarakat untuk menempati janji dengan cara di muka umum

\section{Saran}

Berdasarkan dari hasil penelitian dan pembahasan, maka peneliti memberikan saran yaitu Sebaiknya partai Golkar mengoptimalkan pendekatan dan komunikasi antara para kader-kader partai Golkar dan juga memperluas jaringan kepada masyarakat luas. Memanfaatkan media sosial yang digunakan oleh partai Golkar dalam jangka panjang jangan hanya terbatas pada pemilu saja, karena media sosial dapat digunakan sebagai sarana untuk memberikan kritik dan saran terhadap pemerintah dan juga partai bisa dikritik oleh masyarakat yang sifatnya terbuka oleh umum. Sebaiknya partai Golkar merubah strategi nya karena melihat dari kasus kekalahan pada Pilwakot di tahun 2018, agar tidak terulang kembali. 


\section{DAFTAR PUSTAKA}

Cangara, Hafied. 2009. Komunikasi Politik. Rajagrafindo Persada, Jakarta

Danandjaja. 2011. Peranan Humas Dalam Perusahaan.: Graha IImu, Yogyakarta

Harianto, Rudi. 2016. Strategi Komunikasi Kantor Pemadam Kebakaran Kota

Bengkulu Dalam Mensosialisasikan Peraturan Daerah Nomor 03 Tahun 2013 Tentang Retribusi Pemeriksaan Alat Pemadam Kebakaran. Universitas Dehasen, Bengkulu

Nimmo, Dan. 2004. Komunikasi Politik, Komunikator, Pesan, dan Media. PT Remaja Rosdakarya, Bandung

Nursal, Adam, 2004. Political Marketing Strategi Memenagkan Pemilu Sebuah Pendekatan Baru Kampanye Pemilihan Kepala Daerah, DPR,Presiden. PT Gramedia, Jakarta

Pito, Toni Andrianus. 2013. Mengenal Teori-Teori Politik. Penerbit Nuansa Indah, Bandung

Sugiyono. 2003. Metode Penelitian Bisnis. Pusat Bahasa Depdiknas, Bandung

Sugiyono. 2014. Memahami Penelitian Kualitatif. Alfabeta, Bandung

Sugiyono. 2012. Metode Penelitian Kuantitatif Kualitatif dan R\&D. Alfabeta, Bandung

Triawang, Arief. 2015. Strategi Komunikasi PolitikDedi Humadi Dalam Pemilihan Umum Legislatif Anggota Dewan Perwakilan Rakyat Daerah Kabupaten Rokan Hilir Tahun 2014 : Universitas Riau.

Undang-Undang Republik Indonesia No. 2 Tahun 2008 Tentang Partai Politik.

Undang-Undang Republik Indonesia No. 22 Tahun 1999 Tentang Pemerintahan Daerah.

Undang-Undang Republik Indonesia No. 32 Tahun 2004 Tentang Pemerintahan Daerah.

Venus, Antar. 2007. Manajemen Kampanye. Remaja Rosdakarya offset, Bandung 